\title{
Bioconversion of glycosides isoflavones to aglycone isoflavones by Lactobacillus rhamnosus BHN-LAB 76 under anaerobic conditions
}

\author{
Byung-Hyuk Kim ${ }^{1}$, Jong-Ok Jang ${ }^{2}$, Jun-Hyeong Lee ${ }^{1,2}$, Ye-Eun Park ${ }^{1}$, \\ Jung-Gyu Kim ${ }^{1,2}$, Yeo-Cho Yoon ${ }^{1,2}$, Su Jin Jeong ${ }^{1}$, Gi-Seok Kwon ${ }^{2}$, Jung-Bok Lee ${ }^{1 *}$ \\ ${ }^{1}$ Institute for Development of Bio-industrial Materials, BHNBIO Co., Ltd., Jincheon 27850, Korea \\ ${ }^{2}$ Division of Horticulture \& Medicinal Plant, Andong National University, Andong 36729, Korea
}

\section{혐기성조건에서 Lactobacillus rhamnosus BHN-LAB 76에 의한 배당체 이소플라본의 비배당체 이소플라본으로의 생물전환}

\author{
김병혁 ${ }^{1} \cdot$ 장종옥 $^{2} \cdot$ 이준형 ${ }^{1,2}$ - 박예은 ${ }^{1} \cdot$ 김중규 $^{1,2} \cdot$ 윤여초 $^{1,2} \cdot$ 정수진 $^{1} \cdot$ 권기석 $^{2} \cdot$ 이중복 $^{1 *}$ \\ ${ }^{1}$ 생물산업소재개발연구소 (주비에이치앤바이오 \\ ${ }^{2}$ 안동대학교 원예 · 생약융합학부
}

\begin{abstract}
Isoflavones exhibit an estrogenic activity and have been reported extensively for their potential role in preventing chronic diseases, such as cancer, osteoporosis, and postmenopausal syndrome. Pueraria is a medicinally important leguminous plant producing several glycoside isoflavones, such as daidzin, daidzein, genistin, and puerarin. However, daidzin and genistin mainly exist as nonabsorbable and biologically inactive glycosides. The bioavailability of glucosides is increased by hydrolysis of the sugar moiety using $\beta$-glucosidase. Furthermore, intestinal microorganisms can enhance the biological activity of these isoflavones through biotransformation. Lactic acid bacteria (LAB) are typical probiotic microorganisms used in fermented foods, as feed additives, and in pharmaceuticals. Therefore, we isolated Lactobacillus rhamnosus BHN-LAB 76 from Korean traditional fermented food and assessed its isoflavone-transforming activity in the production of daidzein using HPLC. The Pueraria lobata extract was fermented with $L$. rhamnosus BHN-LAB 76 for $72 \mathrm{~h}$ at $37^{\circ} \mathrm{C}$ under anaerobic conditions. L. rhamnosus BHN-LAB 76 could convert about $25 \%$ of daidzin to daidzein. These results confirmed the potential of $L$. rhamnosus BHN-LAB 76 as a probiotic culture, which can be utilized in the manufacture of fermented and functional foods.
\end{abstract}

Key words : aglycone, bioconversion, glycosides, isoflavone, Lactobacillus

\section{서 론}

이소플라본(isoflavon)은 리그닌(lignin)과 함께 식품에서 발견되는 식물성 에스트로겐(phytoestrogen)으로 에스트로 겐과 유사한 생리활성을 나타내며 장내 미생물에 의해 생리 활성을 나타내는 phytochemical이다. 대두의 이소플라본은

*Corresponding author. E-mail : bio91@bhnbio.com Phone : 82-54-822-8972, Fax : 82-54-822-8973

Received 17 December 2018; Revised 30 January 2019; Accepted 14 February 2019.

Copyright (c) The Korean Society of Food Preservation. All rights reserved. daidzein, genistein, glycitein 3종류의 비배당체(aglycone)와 각각의 배당체(glycoside)인 daidzin, genistin, glycitin을 포 함한 12 종의 존재가 확인되었다(1). 지금까지 이소플라본 연구에 사용된 소재는 대두가 주를 이루고 있다. 그러나 최근에 자연계에 많이 존재하는 칡에도 상당량의 이소플라 본이 존재한다고 보고되고 있다(2-5).

칡(Pueraria thumbergiana Bentham)은 다년생 덩굴성 관 목으로 한국, 일본, 북미 등에서 자생하고 있는 콩과 식물이 다. 칡은 해열작용, 혈압강화작용, 술독제거, 담증과 위액의 분비증가, 저산소증 보호효과 활성, 호흡조절작용 및 심장 박동강화작용, 간손상에 대한 보호효과, 골다공증, 폐경기 질환에 효과가 있는 것으로 보고되었다(6-10). 칡에는 
daidzin, daidzein, genistein, 및 genistein 등이 함유되어 있으 며, daidzin과 daidzein은 대두에도 포함되어 있지만 칡이 더 높은 함량을 가진다고 보고되었다 $(2,11)$. 또한, 대두에서 보고되지 않은 puerarin이 칡에 상당량 $(1-10 \mathrm{~g} / 100 \mathrm{~g})$ 존재하 는 것으로 확인되어 새로운 이소플라본의 공급원으로 활용 할 수 있을 것이다(2).

유산균은 발효를 통해 젖산 및 여러 가지 대사산물을 생산하는 미생물로 각종 발효 식품, 의약품, 사료 첨가제 등에 광범위하게 이용되며, 최근에는 건강 증진 및 질병 예방의 특징을 가지는 probiotics 균주로 연구와 활용이 증 가하고 있다 $(12,13)$. 대표적 유산균인 Lactobacillus rhamnosus는 가장 많이 이용되며, 유산균 발효음료, 전통발 효 음식, 동결건조식품 및 기능성 제품으로 활용되고 있다. 또한, 유산균을 포함하는 장내 미생물은 인간 및 동물의 건강에 영향을 미치는 주요 요인 중의 하나로 인식되고 있다(14-16). 장내 미생물이 장내 환경을 안정하게 유지함 으로써 숙주의 대사 활성 및 면역을 조절하고, 숙주의 생리 에 영향을 주는 것으로 알려져 있다 $(17,18)$.

식물체 내 대부분의 이소플라본은 배당체 형태로 존재하 므로 체내에 흡수되기 위해서는 장내 미생물에 의해 대사산 물체 형태로 전환된 후 체내에 흡수된다. 하지만, 체내흡수 율이 매우 낮아 이를 보완하기 위해 배당체 형태의 이소플 라본을 비당체 형태로 전환하는 생물전환(bioconversion) 공정 기술 및 가공기술이 절실히 필요한 상황이다. 또한, 비배당체 형태의 이소플라본의 생물학적 활성은 에스트로 겐과 유사하여 체내에서 배당체 형태보다 빠르게 흡수된다 고 보고되었다 $(19,20)$. 이소플라본은 주로 포도당 잔기가 B-glucoside 결합을 하고 있는 배당체인 daidzin형태로 존재 하며, 배당체는 체내흡수율이 매우 낮아 이를 보완하기 위 해서는 미생물의 효소인 B-glucosidase에 의하여 가수분해 된 비배당체 형태인 daidzein으로 전환되면 장내 흡수가 증진된다(21,22)(Fig. 1). 또한, 배당체인 daidzin보다 항암활 성 및 혈소판 응집억제효과가 증진되는 것이 보고되었으 며, 배당체 이소플라본은 체내흡수율이 매우 낮아 이를 보 완하기 위해 비배당체 형태로 전환하는 생물전환 공정 기술 의 중요성이 강조되고 있다 $(20,23,24)$. 생리활성을 증진시 키기 위한 비배당화 방법은 가수분해, 효소적 변화와 미생 물에 의한 생물전환이 있다. 다양한 미생물을 통한 생물전 환은 미생물을 비롯한 생명체가 보유한 효소활성을 이용하 여 새로운 물질을 생산하거나 유용성분의 함량을 증진시킬 수 있는 기술이다(25-27). 특히 미생물에 의한 생물전환은 epimerization, hydration, hydroxylation과 같은 부가반응이 적다는 장점을 가진다. 따라서, 생물전환공정에 의한 비배 당체 전환 물질은 면역활성 및 생리활성이 증가된 기능성물 질로 활용 할 수 있을 것이다(28).

본 연구에서는 한국 전통발효식품으로부터 분리된 유산 균을 활용하여 칡의 배당체인 daidzin을 절대혐기성 조건인
장내환경에서 인체로 흡수가 용이한 형태인 비배당체인 daidzein으로 전환할 수 있는 미생물 활성과 활용방안에 대해 기술하고자 한다.

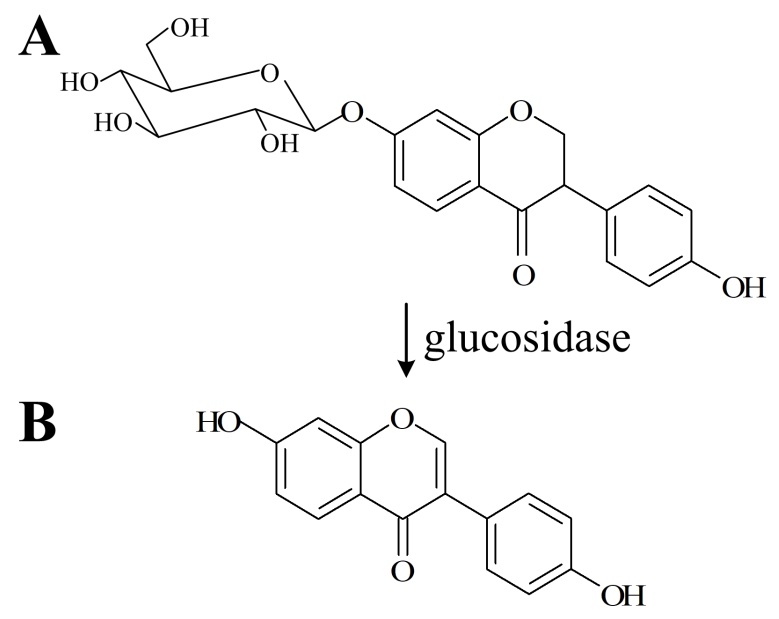

Fig. 1. Metabolic pathway of daidzin by microflora. A, daidzin; B, daidzein.

\section{재료 및 방법}

\section{유산균 분리 및 동정}

본 연구에 사용된 미생물은 전통발효식품인 김치로부터 분리 및 동정한 유산균을 사용하였다(Fig. 2). 분리 유산균 의 미생물 동정은 $16 \mathrm{~S}$ rRNA gene분석을 통해 수행하였다. 미생물 배양액 $1.5 \mathrm{~mL}$ 시료로부터 Fast DNA Spin kit for Soil(MP bio, Santa Ana, CA, USA)을 이용하여 total DNA를 추출하였다. 추출된 total DNA의 농도와 순도는 NanoDrop ND-2000(Thermo Scientific, Wilmington, DE, USA)을 이용 하여 결정하였으며, 시료의 농도는 $50 \mathrm{ng} / \mu \mathrm{L}$ 이상, 순도는 1.8-2.0으로 본 연구를 수행하기에 적합하였다. $16 \mathrm{~S} \mathrm{rRNA}$ gene 분석을 위한 $\mathrm{PCR}$ 은 $27 \mathrm{~F}\left(5^{\prime}\right.$-AGA GTT TGA TCM TGG CTC AG-3')와 1541R(5 ' -AAG GAG GTG ATC CAN CCR CA-3')을 사용하였다(29). 각각의 primer를 이 용하여 $50 \mu \mathrm{L}$ 안에 $1 \times \mathrm{PCR}$ buffer, $20 \mathrm{mM} \mathrm{MgCl}_{2}, 40 \mathrm{mM}$ $\mathrm{dNTP}$ mixture, 각 $\operatorname{primer}(1 \mu \mathrm{M})$, template DNA와 $0.5 \mathrm{U}$ $T a q$ polymerase를 첨가하여 $\mathrm{PCR}$ 을 수행하였다. 반응조건 은 $94^{\circ} \mathrm{C}$ 에서 5 분 동안 $\mathrm{DNA}$ 를 pre-denaturation 시켜, $94^{\circ} \mathrm{C}$ 에 서 1 분간 denaturation, $65^{\circ} \mathrm{C}$ 에서 1 분간 annealing, $72^{\circ} \mathrm{C}$ 에서 1 분 30 초간 extension하고 $72^{\circ} \mathrm{C}$ 에서 5 분 동안 final extension 을 수행하였다. PCR 증폭산물은 $1.2 \%$ agarose gel에 loading 한 후 약 $1,500 \mathrm{bp}$ 크기의 band를 잘라, HiGene ${ }^{\mathrm{TM}} \mathrm{Gel} \&$ PCR Purification Solution Kit(Biofact, Daejeon, Korea)를 이 용하여 정제하여 cloning 하였다. Cloning은 All-in-one PCR cloning kit(Biofact)를 이용하였고, manufacturer's protocol 
을 따라 수행하여 $16 \mathrm{~S}$ rRNA gene의 염기서열을 결정하였 다. 결정된 염기서열은 CAP3 sequence assembly program (http://doua.prabi.fr/software/cap3)을 통해 assemble 하여 $1,500 \mathrm{bp}$ 의 $16 \mathrm{~S}$ rRNA gene을 염기서열을 확인하였으며, $\mathrm{NCBI}$ (www.ncbi.nlm.nih.gov)의 GenBank database를 이용하 여 BLAST search를 통해 분석하였다. 또한, Phylogenetic tree는 ClusterX를 이용하여 분석된 미생물간의 상동성을 분석하고, MEGA 5.0의 neighbor-joining method를 이용하 여 유전적 계통분류를 수행하였다(30).

\section{칡 추출 조건}

본 연구에 사용된 칡은 경북 영천에서 채취한 것을 이용 하였으며, 칡 $200 \mathrm{~g}$ 에 물 $1 \mathrm{~L}$ 를 이용하여 $80^{\circ} \mathrm{C}$ 에서 24 시간 열수 추출한 후, 추출물을 $0.2 \mathrm{~L}$ 로 농축하여 연구에 사용하 였다.

배지 및 혐기성 배양 조건

유산균은 MRS(Difco Laboratories Inc., St. Detroit, MI, USA)에서 계대하였다. 미생물 성장을 위한 혐기성 배지

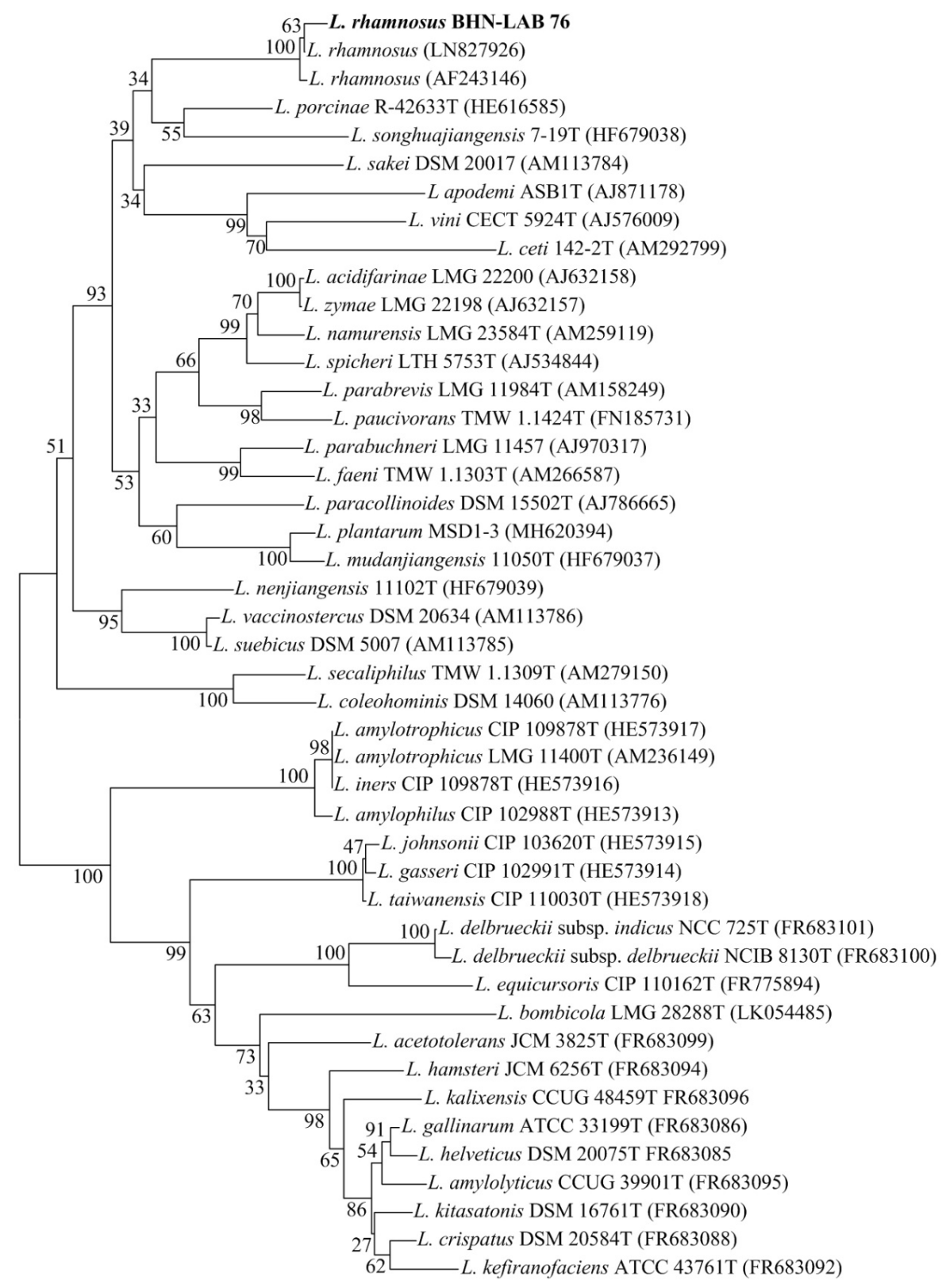

$\longdiv { 0 . 0 1 0 0 }$

Fig. 2. Phylogenetic tree of the L. rhamnosus BHN-LAB 76 and related bacteria of the Lactobacillus group based on 16S rRNA gene sequence comparisons.

The sequences of isolated strains were compared with available from the GenBank database. 
조성은 MRS $11 \mathrm{~g} / \mathrm{L}$, 칡추출물 $200 \mathrm{~mL}$, resazurin $(0.1 \%$ solution) $1 \mathrm{~mL}, \mathrm{~L}$-cysteine $0.031 \mathrm{~g} / \mathrm{L}, \mathrm{NaHCO}_{3} 2.52 \mathrm{~g} / \mathrm{L}$ 를 넣은 후 배지의 $\mathrm{pH} 3.0$ 으로 맞춘 후 $\mathrm{N}_{2} / \mathrm{CO}_{2}$ 가스로 산소를 치환하여 혐기성 상태를 만들었다. 혐기성 배지는 $160 \mathrm{~mL}$ serum병에 $50 \mathrm{~mL}$ 을 분주하였으며, 알루미늄 실링을 통해 혐기성 배지를 산소와 차단한 후 고온증기멸균기를 통해 멸균하였다. 혐기성 배양 무균대(Vinyl anaerobic chamber, Coy, Grass Lake, MI, USA)에서 유산균을 접종하였으며, 접종된 혐기성 serum병은 $37^{\circ} \mathrm{C}$ 진탕배양기 $150 \mathrm{rpm}$ 으로 3 일간 배양하였으며, 배양 시간대별로 시료를 채취하였다.

\section{칡을 이용한 daidzin에서 daidzein의 생물전환 분석} 배양액에서 배당체 이소플라본인 daidzin과 유산균에 의 해 생성된 비배당체인 daidzein의 정량을 위해, HPLC를 이용하여 분석하였다. 혐기성 배양액을 배양 시간에 따라 회수하여, 원심분리 후 상등액을 취하여 $0.45 \mu \mathrm{m} \mathrm{PTEF}$ syringe filter로 여과한 시료를 HPLC(1260 Infinity II LC system, Agilent Technologies, Santa Clara, CA, USA)로 분석 하였다. 시료의 분석은 Eclipse plus $\mathrm{C}_{18}$ column $(4.6 \mathrm{~mm} \times 250$ $\mathrm{mm}, 5 \mu \mathrm{m}$, Agilent Technologies)을 사용하였으며, 컬럼 온 도는 $30^{\circ} \mathrm{C}$ 로 설정하였다. 이동상으로는 acetonitrile: methonol:DW(0.3:0.2:0.5)를 이용하여 이동상의 유속은 1 $\mathrm{mL} / \mathrm{min}$ 으로 분석하며, $270 \mathrm{~nm}$ 파장에서 흡광도를 측정하 였다. Daidzin과 daidzein 표준물질은 Sigma-Aldrich Korea 에서 구입하였으며, Daidzin과 daidzein의 함량은 표준물질 을 이용하여 표준검량곡선을 작성하여 3회 반복 측정하였 다. 또한, 시간에 따른 daidzin과 daidzein의 함량을 측정한 후, L. rhamnosus BHN-LAB 76의 생물전환율을 분석하여, 시간대별로 생물전환율을 분석하였다(section $1,0-5 \mathrm{~h}$; section 2, 5-12 h; section 3, 12-17 h; section 4, 17-25 h; section 5, 25-48 h; section 6; 48-72 h).

\section{발효 미생물 정량분석}

각 시료별 미생물의 군집의 크기를 정량적으로 평가하기 위해 $\mathrm{qPCR}$ 을 수행하였다. 미생물 군집을 정량하기 위해서 Lacto-F(5 ' -GCA GCA GTA GGG AAT CTT CCA-3' $)$ 와 Lacto-R(5' -GCA TTY CAC CGC TAC ACA TG-3') primer를, E. coil $\mathrm{DH} 5 \mathrm{a}$ 의 total $\mathrm{DNA}$ 를 주형으로 $\mathrm{PCR}$ 을 수행하여 $350 \mathrm{bp}$ 의 PCR 산물을 얻었다(31). 각각의 PCR 산물은 All-in-one vector(Biofact)에 cloning하였으며, plasmid DNA는 HiGene ${ }^{\mathrm{TM}}$ Plasmid Mini Prep Kit(Biofact)를 이용하여 추출하였다. 염기서열분석은 M13-20F(All-in-one Vector Systems manual)를 이용하여 분석하였고, BLAST search를 통해 확인하였다. 염기서열이 확인된 plasmid DNA는 Real-time PCR(CFX96 Touch ${ }^{\mathrm{TM}}$ Real-Time PCR Detection System, Bio-Rad, Hercules, CA, USA)를 이용하여 melting curve 분석 후 정량분석을 위한 표준 유전자 (artificial standard clone)로 사용하였다.

정량 $\mathrm{PCR}$ 을 위해 Real-time PCR과 $\mathrm{iTaq}^{\mathrm{TM}} \mathrm{SYBR}^{\circledR}$ Green Supermix with ROX(Bio-Rad)를 이용하였다. Lactobacillus sp. 16S rRNA gene 정량 PCR은 Lacto-F/R를 이용하였고 (31), 반응조건은 $95^{\circ} \mathrm{C}$ 에서 15 분 동안 pre-denaturation 시켜, $95^{\circ} \mathrm{C}$ 에서 30 초 denaturation, $67^{\circ} \mathrm{C}$ 에서 30 초 annealing, $72^{\circ} \mathrm{C}$ 에서 30초 extension 후 fluorescence를 측정하고 45 cycles을 수행하였다. 그리고 final extension은 $72{ }^{\circ} \mathrm{C}$ 에서 5 분 동안 수행하였다. Melting curve 분석은 $65^{\circ} \mathrm{C}$ 부터 $95^{\circ} \mathrm{C}$ 까지 $0.2^{\circ} \mathrm{C}$ 씩 증가시키면서 fluorescence를 측정하였다(32).

정량을 위해서 표준 유전자를 serial dilutions하여 Real-time-PCR을 수행하였으며, DNA 농도는 NanoDrop ND-2000(Thermo Scientific)을 이용하여 $1 \mathrm{ng} / \mathrm{uL}$ 를 분석에 이용하였다(32).

\section{결과 및 고찰}

\section{혐기성 장내환경에서 성장 가능한 유산균의 동정}

초기시료내의 배당체인 daidzin의 농도는 $841.3 \pm 21.0$ $\mathrm{ppm}$, 약 $97.9 \%$ 수준으로 확인되었으며, 비배당체인 daidzein은 $17.8 \pm 2.6 \mathrm{ppm}$, 약 $2.1 \%$ 수준으로 확인되어 매우 미미한 것으로 확인되었다. 따라서 본 연구에서 daidzin을 daidzein으로 생물전환 효능이 우수한 미생물을 선별하기 위해, 전통발효식품인 김치로부터 분리 및 동정한 미생물 들을 이용하여 장내 환경인 혐기성 조건에서 성장, 내산산 성, 내담즙성 및 췌장효소 실험을 통해 선발하였으며, 내산 성 조건인 $\mathrm{pH}$ 3.5에서 48시간 배양한 후 시료내 daidzin을 daidzein의 전환이 우수한 균주를 선발하였다(data not shown). 해당 균주는 김치로부터 분리된 유산균으로, 선발 균주의 $16 \mathrm{~S} \mathrm{rRNA}$ gene을 분석한 결과 Lactobacillus rhamnosus와 $99 \%$ 유사도를 갖는 것으로 분석되었다. 또한, 분석된 $16 \mathrm{~S}$ rRNA gene sequence를 이용하여 유전적 계통도 를 분석한 결과, Lactobacillaceae에 속하고, L pantheris, L. camelliae, L. sakai, L. plantarum등의 species 수준에서 구별되는 것을 확인하여 L. rhamnosus BHN-LAB 76이라 명명하였으며, 한국생명공학연구원 생물자원센터(KCTC 13647BP)에 기탁하였다.

\section{칡을 이용한 daidzin에서 daidzein의 전환}

칡 추출물 $20 \%$ 를 포함한 혐기성 배지에 배당체 이소플라 본 daidzin은 $841.3 \pm 21.0 \mathrm{ppm}$ 수준이었으며, 비배당체 daidzein은 $17.8 \pm 2.6 \mathrm{ppm}$ 으로 매우 낮은 농도를 확인하여 대부분 daidzin이 높은 농도로 존재하는 것을 확인하였다. 칡 추출물과 L rhamnosus BHN-LAB 76을 이용한 생물전환 배양은 장내 환경인 혐기성 상태에서 실시하였으며, 배양 시간에 따라 daidzin에서 daidzein으로 생물전환량의 확인 
은 HPLC를 통해 정량분석하여 시간에 따른 생물전환능을 평가하였다(Fig. 3 \& Table 1). Daidzin을 포함하는 혐기성 배양액은 접종 후 $5,12,17,25,48,72$ 시간에 각각 시료를 채취하여, daidzin 농도 분석결과 각각 $830.3 \pm 12.5 \mathrm{ppm}$, $780.0 \pm 11.6 \mathrm{ppm}, 693.4 \pm 9.0 \mathrm{ppm}, 639.3 \pm 16.0 \mathrm{ppm}$, $630.9 \pm 9.5 \mathrm{ppm}, 614.5 \pm 15.1 \mathrm{ppm}$ 으로 분석되었으며, 배양 초기부터 배양 종료시점까지 daidzin 농도가 지속적으로 감소하는 것을 확인하였다. 또한, 배양 후 $5,12,17,25$, 48,72 시간의 시료 내 daidzein의 농도는 각각 $20.6 \pm 1.1 \mathrm{ppm}$, $55.6 \pm 5.6 \mathrm{ppm}, 121.2 \pm 7.1 \mathrm{ppm}, 167.3 \pm 7.5 \mathrm{ppm}, 188.2 \pm 8.5$ $\mathrm{ppm}, 210.3 \pm 13.7 \mathrm{ppm}$ 으로 분석되었으며, 배양 전기간에 걸쳐 지속적으로 증가하는 것을 확인하였다.

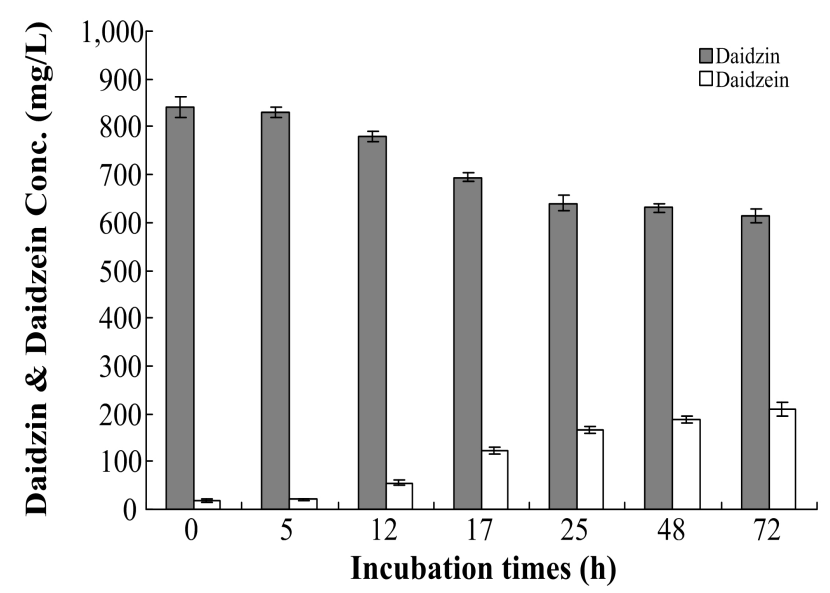

Fig. 3. Change of daidzin and daidzein by $L$. thamnosus BHN-LAB 76 in intestinal anaerobic conditions.

Table 1. Quantification of the daidzin and daidzein using the HPLC (ppm)

\begin{tabular}{ccccc}
\hline \multirow{2}{*}{ Time (h) } & \multicolumn{2}{c}{ Daidzin } & \multicolumn{2}{c}{ Daidzein } \\
\cline { 2 - 5 } & Concentration & Composition & Concentration & Composition \\
\hline 0 & $841.3 \pm 21.0$ & $97.9 \%$ & $17.8 \pm 2.6$ & $2.1 \%$ \\
5 & $830.3 \pm 12.5$ & $97.6 \%$ & $20.6 \pm 1.1$ & $2.4 \%$ \\
12 & $780.0 \pm 11.6$ & $93.4 \%$ & $55.6 \pm 5.6$ & $6.6 \%$ \\
17 & $693.4 \pm 9.0$ & $85.1 \%$ & $121.2 \pm 7.1$ & $14.9 \%$ \\
25 & $639.3 \pm 16.0$ & $79.3 \%$ & $167.3 \pm 7.5$ & $20.7 \%$ \\
48 & $630.9 \pm 9.5$ & $77.0 \%$ & $188.2 \pm 8.5$ & $23.0 \%$ \\
72 & $614.5 \pm 15.1$ & $74.5 \%$ & $210.3 \pm 13.7$ & $25.5 \%$ \\
\hline
\end{tabular}

L. rhamnosus BHN-LAB 76의 daidzin에서 daidzein으로 생물전환율은 접종 후 5 시간까지(section 1) $0.4 \%$ 였으나, 5 시간부터 12시까지(section 2)는 $4.2 \%, 12$ 시간부터 17시간 까지(section 3 )는 $8.2 \%$ 로 매우 전환율이 증가되는 것을 확인하였다. 그리고, 17 시간부터 25 시간까지(section 4)의 daidzein으로 전환율은 $5.9 \%$ 로 감소되어 25 시간부터 (section 5 \& 6)는 2.2-2.5\%의 전환율을 확인하였다(Fig. 4A).
이를 통해, 접종 25 시간까지 L. rhamnosus BHN-LAB 76에 의한 daidzein의 생산이 빠르게 일어나며, 25 시간 이후부터 는 daidzein으로의 생물전환이 매우 느리게 일어나는 것을 확인하였다. 일반적으로 전체 대장통과시간은 서양인의 경 우 12-30시간, 한국인의 대장통과시간은 평균 8-23시간으 로 보고되고 있다(33). 한국인의 평균 대장통과시간에 미루 어, L. rhamnosus BHN-LAB 76이 장내에 머물며 배당체를 비배당체로 전환할 수 있으며, 이를 통해 생물전환된 비배 당체의 인체흡수율을 높일 수 있을 것으로 판단된다. 또한, daidzin에서 daidzein으로 시간당 전환능은 $0.23 \mathrm{ppm} / \mathrm{h}$ (section 1), $0.38 \mathrm{ppm} / \mathrm{h}$ (section 2), $0.44 \mathrm{ppm} / \mathrm{h}$ (section 3)였으 며, section 4 에서는 $0.17 \mathrm{ppm} / \mathrm{h}$ 로 감소되고, section 5 부터 배양 종료시까지 $0.05 \mathrm{ppm} / \mathrm{h}$ 로 유지되는 것을 확인하였다 (Fig. 4B). 이를 통해, L. rhamnosus BHN-LAB 76은 장내 혐기성 상태에서 약 25 시까지 식물이 함유한 배당체 이소 플라본인 daidzin을 비배당체인 daidzein으로 전체 생물전 환량의 $47.8 \%$ 를 전환하며, 배양시간에 따른 생물전환능은 $5.98 \mathrm{ppm} / \mathrm{h}$ 로 분석되었다. 이를 통해, 장내 혐기성 상태에서 daidzin의 daidzein으로 전환율 및 전환능은 접종 후 17시까 지 증가하고, 25 시간 이후는 매우 낮은 전환율과 전환능이 있음을 확인하였다.

일반적인 이소플라본의 경우 대부분 생물학적으로 비활 성 상태인 glucosides가 $80 \%$ 이상의 비율로 존재하며, 이소 플라본 내 배당체의 당을 제거하여 비배당체로 전환하려는 연구가 많이 진행되고 있으며, 이소플라본을 생물학적 활 성 변화에 대한 연구도 활발히 이루어고 있다. 생물전환 (biotransformation 또는 bioconversion)은 세포수준의 대사 과정 또는 효소를 활용하여 유용물질을 생산하는 것으로, 합성화학공업의 제반 문제점을 해결하는 첨단 유용물질 생산방식으로 자리매김하고 있다 $(23,34,35)$. 특히, 미생물 에 의한 생물전환은 epimerization, hydration, hydroxylation 과 같은 부가반응이 적은 장점을 가지고 있다(23). 두유액을 이용하여 L. gasseri, L. plantarum, Pediococus pentosaceus, Enterococcus sp. 등의 균주를 이용하여 18 시간 배양한 후 시료내에 이소플라본을 측정한 결과 약 $1-41 \%$ 정도로 daidzin을 daidzein으로 전환한다고 보고되었다. 이 중, $L$. plantarum ATCC 8014는 $40.65 \%$ 의 높은 생물전환율을 보 고하였다(23). 또한, $L$ bulgaricus, $L$. casei, $L$ delvrueckii로 두유를 발효시킬 때 daidzin과 genistein을 가수분해할 수 있으며, 두유에 유산균과 bifidobacteria를 함께 접종하여 배당체의 가수분해를 증가시킬 수 있다고 보고하고 있다 (35). 유산균에 의한 배당체의 비배당체로의 전환은 유산균 의 종류에 따라 다르게 나타나며, L. casei subsp. rhamnosus 의 B-glucosidase가 세포에 결합한 상태로 존재하여, 이소플 라본 배당체의 가수분해에 관여한다고 알려져 있다(34). Daidzin에서 daidzein으로 생물전환은 $\beta$-glucosidase의 활성 과 매우 밀접하게 관련되어 있으며, Lactobacillus sp., 

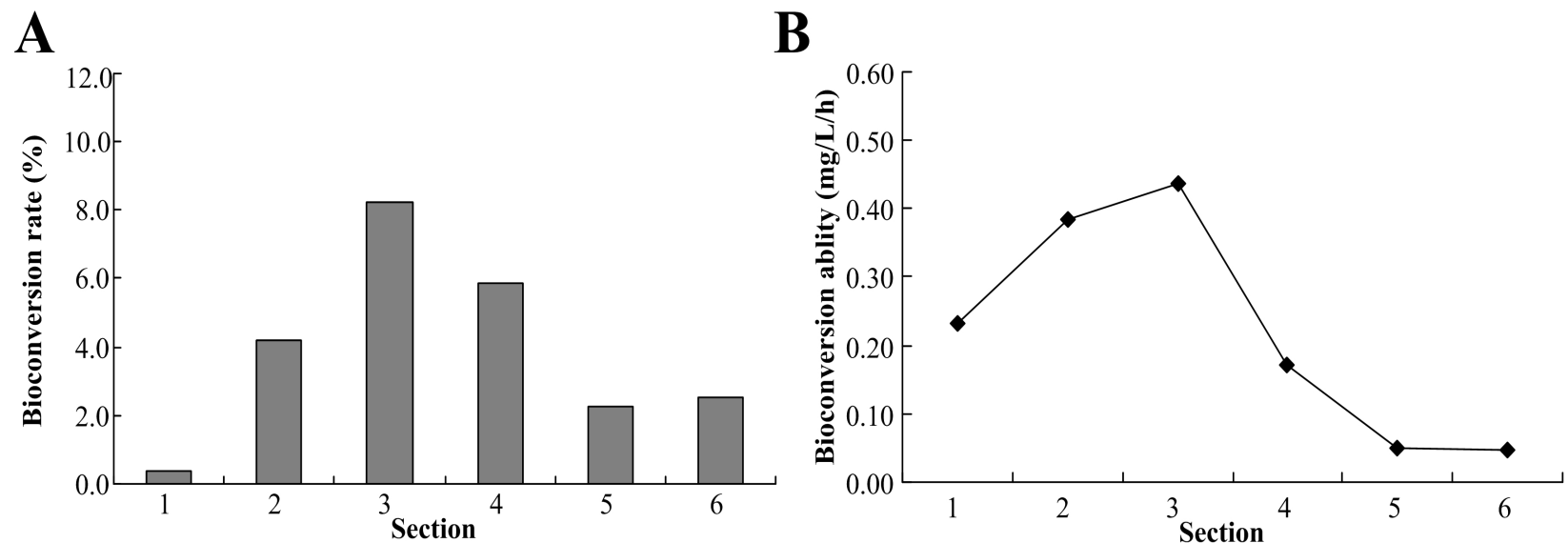

Fig. 4. Bioconversion rate (A) and ability (B) from daidzin to daidzein of $L$. rhamnosus BHN-LAB 76 in intestinal anaerobic conditions. Section 1, 0-5 h; section 2, 5-12 h; section 3, 12-17 h; section 4, 17-25 h; section 5, 25-48 h; section 6, 48-72 h.

Bifidobacterium sp. Bacteroides sp.와 Streptococcus sp. 등이 생산하는 것으로 알려져 있다 $(34,35)$. 그러나 이 미생물들 의 이소플라본 생물전환능은 호기성 조건에서 분석하였다. 반면, 본 연구는 장내환경인 혐기성 조건에서 미생물의 성 장과 이에 따른 이소플라본의 생물전환능을 확인하기 위해 호기성 조건에서 생물전환능을 확인하지 않았다. 본 연구 에 사용된 L. rhamnosus BHN-LAB 76은 혐기성 조건에서 배양하여 배당체 이소플라본을 비배당체 이소플라본으로 생물전환하는 것을 확인하였다. 본 연구는 기존의 호기성 배양 연구가 아닌 장내 환경과 유사한 혐기성 연구로서 칡 추출물과 L. rhamnosus BHN-LAB 76을 배양하였으며, 배양 17 시간 후 약 $15 \%, 25$ 시간 후 약 $21 \%$ 의 daidzein으로 전환되는 것을 확인하였다. 또한, 장내 환경인 혐기성 조건 에서 이소플라본의 생물전환능을 분석한 연구는 매우 부족 한 실정이다. 이를 통해, 실제 장내환경에서 유산균의 생물 전환 가능성을 확인하였으며, 이를 통해 건강기능식품 및 생물소재로서의 활용 가능성을 확인하였다.

\section{발효 균주 growth curve}

시간에 따른 배양액 내의 L. rhamnosus BHN-LAB 76의 성장을 Real-time PCR을 통해 확인하였으며, 초기 접종은 $6.88 \times 10^{3} \pm 6.57 \times 10^{3}$ copy molecule/ $\mathrm{LL}$ 으로 확인되었다. Daidzin 을 포함하는 혐기성 배양액을 접종한 후 $5,12,17,25,48$, 72시간에 각각 시료를 채취하여 L. rhamnosus BHN-LAB 76 의 $16 \mathrm{~S}$ rRNA gene copy를 분석한 결과, 각 채취 시간별로 $8.28 \times 10^{4} \pm 1.26 \times 10^{4}$ copy molecule $/ \mu \mathrm{L}, 2.36 \times 10^{5} \pm 2.55 \times 10^{4}$ copy molecule $/ \mu \mathrm{L}, \quad 5.36 \times 10^{5} \pm 7.40 \times 10^{4}$ copy molecule $/ \mu \mathrm{L}$, $2.17 \times 10^{6} \pm 1.72 \times 10^{5}$ copy molecule $/ \mathrm{HL}, 2.17 \times 10^{6} \pm 1.72 \times 10^{5}$ copy $\cdot$ molecule $/ \mu \mathrm{L}, \quad 3.00 \times 10^{6} \pm 1.86 \times 10^{5}$ copy $\cdot$ molecule $/ \mu \mathrm{L}$, $2.88 \times 10^{6} \pm 4.46 \times 10^{5}$ copy molecule $/ \mu \mathrm{L}$ 로 미생물 성장을 확 인하였다(Fig. 5 \& table 2), 혐기성 상태의 L. rhamnosus BHN-LAB 76 성장은 접종 초기부터 17시까지 낮은 성장
을 보였으며, 접종 17 시간 이후에 미생물성장이 급격하게 증가하는 것을 확인하였다. 또한, 접종 48 시간 이후 미생물 성장이 둔화되는 것을 확인하였다. 이는, L. rhamnosus $\mathrm{BHN}-\mathrm{LAB}$ 76이 성장과정에서 생물전환 과정을 통해 daidzin을 daidzein으로 전환한다고 판단되어지며, $L$. rhamnosus BHN-LAB 76과 전구물질인 daidzin을 이용하여 장내에서 daidzein을 생성할 수 있다고 추론할 수 있다.

장내 유익균인 Lactobacillus sp.와 Bifidobacterium sp.을 이용하여 대두 추출분말을 발효시킨 배양액에서 24 시간 이후부터 산도 및 유산균수가 가장 활발하게 증가하였고, 시간이 경과함에 따라 $\beta$-glucosidase의 활성이 증가하면서, 배당체 형태의 daidzin, genistin이 감소한다고 보고하였다 (36). 이와 유사하게 칡 추출물에 유산균을 접종한 혐기성 배양액에서 17시간 이후 L rhammosus BHN-LAB 76의 성장 이 매우 급격하게 증가하는 것을 확인하였다. 또한, 장내환 경인 혐기성 상태에서 L rhamnosus BHN-LAB 76의 성장과 배양에 따른 배당체 이소플라본과 비배당체 이소플라본의 물질 분석결과, $L$. rhammosus BHN-LAB 76의 성장에 따라 비배당체 이소플라본인 daidzein 함량이 증가가 매우 유사 한 경향을 확인하였다.

생물전환은 생체 및 생촉매의 기능을 활용하여 의약품, 의약품 원료물질, 비타민, 유용 아미노산, 인지질, 식품원 료, 농업용 화학제품 등을 포함한 다양한 화학제품의 생산 에 활용할 수 있는 기술이다(37). 현재 유산균 및 GRAS(generally recognized as safe) 미생물을 이용하여 생 물전환공법을 활용하여 엉겅퀴, 녹차, 양파, 인삼, 대두 등 여러 물질의 생리활성 증대를 높이고자 이뤄지는 다양한 시도들이 보고되고 있다(23,26,38-40).

본 연구에서는 다량의 이소플라본인 daidzin을 함유한 칡 추출물과 한국 전통발효식품으로 분리된 GRAS 미생물 인 L. rhamnosus BHN-LAB 76을 이용하여 장내 환경인 혐기성 상태에서 배당체인 daidzin이 비배당체인 daidzein 
으로의 전환을 확인하였으며, 이에 따른 생물전환율을 확 인하였다. 또한, 본 연구는 L. rhamnosus BHN-LAB 76을 활용한 혐기성 생물전환을 연구를 통해 장내환경에서도 성장이 가능하고 장내에서도 생물전환이 가능하다는 것을 확인하였으며, 이를 활용한 새로운 식품이나 건강기능성식 품 소재로서 활용이 가능이 매우 높다고 판단된다.

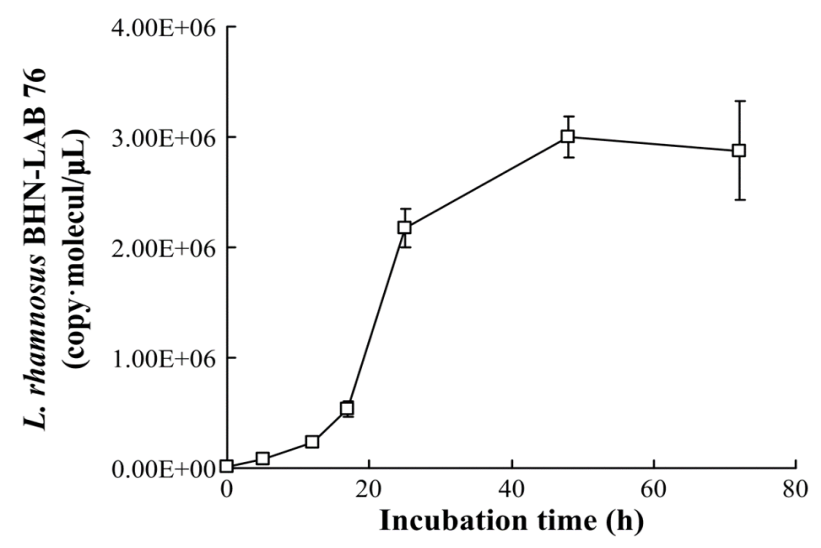

Fig. 5. Quantitative analysis of $L$. rhamnosus BHN-LAB 76 in the intestinal anaerobic fermentation process by the Real-time PCR.

Table 2. Quantification of $L$. rhamnosus BHN-LAB 76 in the intestinal anaerobic fermentation process using the Lactobacillus sp. 16S rRNA gene by the Real-time PCR

\begin{tabular}{cc}
\hline & L. rhamnosus BHN-LAB 76 (copy molecule $/ \mu \mathrm{L})$ \\
\hline $5 \mathrm{~h}$ & $6.88 \times 10^{3} \pm 6.57 \times 10^{3}$ \\
$5 \mathrm{~h}$ & $8.28 \times 10^{4} \pm 1.26 \times 10^{4}$ \\
$12 \mathrm{~h}$ & $2.36 \times 10^{5} \pm 2.55 \times 10^{4}$ \\
$17 \mathrm{~h}$ & $5.36 \times 10^{5} \pm 7.40 \times 10^{4}$ \\
$25 \mathrm{~h}$ & $2.17 \times 10^{6} \pm 1.72 \times 10^{5}$ \\
$48 \mathrm{~h}$ & $3.00 \times 10^{6} \pm 1.86 \times 10^{5}$ \\
$72 \mathrm{~h}$ & $2.88 \times 10^{6} \pm 4.46 \times 10^{5}$ \\
\hline
\end{tabular}

\section{요 약}

칡(Pueraria thumbergiana Bentham)은 한국, 일본 등에서 자생하는 콩과 식물로 해열작용, 혈압강화작용, 술독제거, 담증과 위액의 분비증가, 저산소증 보호효과 활성, 호흡조 절작용 및 심장박동강화작용, 간손상에 대한 보호효과, 골 다공증, 폐경기 질환에 효과가 있는 것으로 보고되었다. 식물성 이소플라본은 만성질환, 암, 골다공증 및 폐경증후 군을 예방하는데 잠재적 도움을 준다고 알려져 있다. 또한, 칡에는 daidzin, daidzein, genistein, 및 genistein등의 배당체 이소플라본을 함유하고 있으며, 매우 높은 함량의 puerarin 을 함유하고 있다. 그러나, 칡에 주요성분인 daidzin과 같은
이소플라본은 인체에 흡수가 어려운 배당체형태로 존재하 고 있다. 배당체 생체이용률은 $\beta$-glucosidase에 의한 가수분 해를 통해 생물학적 활성을 증진시킬 수 있다. 또한, 장내미 생물은 생물전환을 통해 이소플라본의 생물학적 활성을 증진시킬 수 있다. 또한, 배당체인 daidzin보다 항암활성 및 혈소판 응집억제효과가 증진되는 것이 보고되었으며, 배당체 이소플라본은 체내흡수율이 매우 낮아 이를 보완하 기 위해 비배당체 형태로 전환하는 생물전환 공정 기술의 중요성이 강조되고 있다. 유산균은 발효식품, 사료 첨가제 및 의약품을 비롯한 다양한 분야에서 활용되는 프로바이오 틱스 미생물이다. 본 연구에서는 daidzein을 생물전환하는 미생물 Lactobacillus rhamnosus BHN-LAB 76을 분리하였 으며, daidzein의 생물학적 생산을 HPLC로 평가하였다. 칡 추출물은 혐기성 조건에서 L. rhamnosus BHN-LAB 76을 접종하여 $37^{\circ} \mathrm{C}$ 에서 72 시간 동안 발효하였다. L rhamnosus BHN-LAB 76은 혐기성 조건에서 daidzin을 daidzein으로 약 $25 \%$ 전환시키는 것을 확인하였다. 이러한 결과를 통해, L. rhamnosus BHN-LAB 76은 발효 식품 및 기능성 물질을 생산하는 probiotic 소재로 활용 가능성을 확인하였다.

\section{감사의 글}

This research was financially supported by the Ministry SMEs and Startups (MSS), Korea, under the "Regional Specialized Industry Development Program" supervised by the Korea Institute for Advancement of Technology (KIAT).

\section{References}

1. Shigemitsu K, Makoto S, Takashi I, Teiji U, Kazuyoshi O (1991) A new isoflavone glycoside in soybean seeds (Glycine max Merrill), glycitein 7-O- $\beta-\mathrm{d}-\left(6^{\prime \prime}-\mathrm{O}-\mathrm{Acetyl}\right)-$ glucopyranoside. Agric Biol Chem, 55, 859-860

2. Kim HY, Hong JH, Kim DS, Kang KJ, Han SB, Lee EJ, Chung HW, Song KH, Sho KA, Kwack SJ, Kim SS, Park KL, Lee SK, Kim MC, Kim CM, Song IS (2003) Isoflavone content and estrogen activity in arrowroot Puerariae Radix. Food Sci Biotechnol, 12, 29-35

3. Wang S, Yang Z, Peng N, Zhou J, Yong X, Yuan H, Zheng $T$ (2018) Optimization of ionic liquids-based microwave-assisted hydrolysis of puerarin and daidzein derivatives from Radix Puerariae Lobatae extract. Food Chem, 256, 149-155

4. Kim YS, Lee IS, Kim JS (2014) Protective effects of Puerariae radix extract and its single compounds on 
methylglyoxal-induced apoptosis in human retinal pigment epithelial cells. J Ethnopharmacol, 152, 594-598

5. Xiao W, Wang FQ, Li CH, Zhang Q, Xia ZN, Yang FQ (2015) Determination of eight isoflavones in Radix Puerariae by capillary zone electrophoresis with an ionic liquid as an additive. Anal Methods, 7, 1098-1103

6. Han SH, Kim JB, Min SG, Lee CH (1995) The effect of Puerariae radix catechins administration on liver function in carbon tetrachloride-treated rats. J Korean Soc Food Sci Nutr, 24, 713-719

7. Keung WM, Vallee BL (1993) Daidzin a potent selective inhibitor of human mitochondrial aldehyde dehydrogenase. Proc Natl Acad Sci USA, 90, 1247-1251

8. Oh MJ, Lee KS, Son HY, Kim SY (1990) Antioxidative components of Pueraria root. Korean J Food Sci Technol, 22, 793-798

9. Zang Z, Lam TN, Zuo Z (2013) Radix puerariae: An overview of its chemistry, pharmacology, pharmacokinetics, and clinical use. J Clin Pharmacol, 53, 787-811

10. Cherdshewasart W, Subtang S, Dahlan W (2007) Major isoflavonoid contents of the phytoestrogen rich-herb Pueraria mirifica in comparison with Pueraria lobata. J Pham Biomed Anal, 43, 428-434

11. Kaufman PB, Duke JA, Brielmann H, Boik J, Hoyt JE (1997) A comparative survey of leguminous plants as sources of the isoflavones, genistein and daidzein: Implications for human nutrition and health. J Altern Compl Med, 3, 7-12

12. Ljungh A, Wadstrom $\mathrm{T}$ (2006) Lactic acid bacteria as probiotics. Curr Issues Intestinal Microbiol, 7, 73-90

13. Saez-Lara MJ, Gomez-Llorente C, Plaza-Diaz J, Gil A (2015) The role of probiotic lactic acid bacteria and bifidobacteria in the prevention and treatment of inflammatory bowel disease and other related diseases: A systematic review of randomized human clinical trials. Biomed Res Int, E505878

14. Valeria DA, Salvatore F (2015) The role of the gut microbiome in the healthy adult status. Clinica Chimica Ata, 451, 97-102

15. Coreen LJ, James V (2012) The human microbiome and its potential importance to pediatrics. Pediatrics, 129, 950-960

16. Mao B, Li D, Zhao J, Liu X, Gu Z, Chen YQ, Zhang $\mathrm{H}$, Chen $\mathrm{W}$ (2014) In vitro fermentation of lactulose by human gut bacteria. J Agric Food Chem, 62, 10970-10977

17. Hemarajata P, Versalovic J (2012) Effects of probiotics on gut microbiota: mechanisms of intestinal immunomodulation and neuromodulation. Ther Adv Gastroenterol, 6, 39-51

18. O'Connor EM, O'Herlihy EA, O'Toole PW (2014) Gut microbiota in older subjects: variation, health consequences and dietary intervention prospects. Proc Nutr Soc, 73, 441-451

19. Setchell KDR, Cassidy A (1999) Dietary isoflavones: Biological effects and relevance to human health. J Nutr, 129, 758-767

20. Izumi T, Piskula MK, Osawa S, Obata A, Tobe K, Saito M, Kataoka S, Kubota Y, Kikuchi M (2000) Soy isoflavone aglycones are absorbed faster and in higher amounts than their glucosides in humans. J Nutr, 130, 1695-1699

21. Yuan JP, Wang JH, Liu X (2007) Metabolism of dietary soy isoflavones to equol by human intestinal microflora-implications for health. Mol Nutr Food Res, 51, 765-781

22. Ioku K, Pongpiriyadach Y, Konishi Y, Takei Y, Nakatani $\mathrm{N}$, Terao SJ (1998) $\beta$-Glucosidase activity in the rat small intestine toward quercetin monoglucosides. Biosci Biotechnol Biochem, 62, 1428-1431

23. Cho YH, Imm JY, Kim HY, Hong SG, Hwang SJ, Park DJ, Oh S (2009) Isolation and partial characterization of isoflavone transforming Lactobacillus plantarum YS712 for potential probiotic use. Korean J Food Sci Ani Resour, 29, 640-646

24. Murota K, Shimizu S, Miyamoto S, Izumi T, Obata A, Kikuchi M, Terao J (2002) Unique uptake and transport of isoflavone aglycones by human intestinal caco- 2 cells: Comparison of isoflavonoids and flavonoids. J Nutr, 132, 1956-1961

25. Park BY, Hwang HL, Lee JA, Sohn SO, Lee SH, Jung MY, Lim HI, Park HW, Lee JH (2017) Evaluation of ginsenoside bioconversion of lactic acid bacteria isolated from kimchi. J Ginseng Res, 41, 524-530

26. Park YE, Kim BH, Yoon YC, Kim JK, Lee JH, Kwon GS, Hwang HS, Lee JB (2018) Total polyphenol contents, flavonoid contents, and antioxidant activity of roasted-flaxseed extracts based on lactic-acid bacteria fermentation. J Life Sci, 28, 547-554

27. Yoon YC, Kim BH, Kim JK, Lee JH, Park YE, Kwon GS, Hwang HS, Lee JB (2018) Verification of biological activities and tyrosinase inhibition of ethanol extracts from Hemp Seed (Cannabis sativa L.) fermented with lactic acid bacteria. J Life Sci, 28, 688-696

28. Kim JS, Lee JH, Surh J, Kang SA, Jang KH (2016) 
Aglycone isoflavones and exopolysaccharides produced by Lactobacillus acidophilus in fermented soybean paste. Prev Nutr Food Sci, 21, 117-123

29. Forney LJ, Zhou X, Brown CJ (2004) Molecular microbial ecology: land of the one-eyed king. Curr Opin Microbiol, 7, 210-220

30. Tamura K, Peterson D, Peterson N, Stecher G, Nei M, Kumar S (2011) MEGA5: Molecular evolutionary genetics analysis using maximum likelihood, evolutionary distance, and maximum parsimony methods. Mol Biol Evol, 28, 2731-2739

31. Castillo M, Martin-Orue SM, Manzanilla EG, Badiola I, Martin MJG (2006) Quantification of total bacteria, enterobacteria and lactobacilli populations in pig digesta by real-time PCR. Vet Microbiol, 114, 165-170

32. Kim BH, Jang JO, Joa JH, Kim JA, Song SY, Lim CK, Kim CH, Jung YB, Seong KC, Kim HS, Moon DG (2017) A comparison of the microbial diversity in Korean and Chinese post-fermented teas. Microbiol Biotechnol Lett, $45,71-80$

33. Kim YH, Sim SG, Cho KR, Kim JB, Lee OY, Choi HS, Hahm JS, Lee MH (2003) Colonic transit time in patient with liver cirrhosis. Korean J Gastroenterol, 42, 394-399

34. Matsuda S, Norimoto F, Matsumoto $Y$, Ohba R, Teramoto Y, Ohta N, Ueda S (1994) Solubilization of a novel isoflavone glycoside-hydrolyzing $\beta$-glucosidase from Lactobacillus casei subsp. rhamnosus. J Ferment Bioeng, 77, 439-441
35. Chien HL, Huang HY, Chou CC (2006) Transformation of isoflavone phytoestrogens during the fermentation of soymilk with lactic acid bacteria and bifidobacteria. Food Microbiol, 23, 772-778

36. Kim IB, Shin S, Lim BL, Seong GS, Lee YE (2010) Bioconversion of soybean isoflavone by Lactobacillus plantarum and Bifidobacterium longum Korean J Food Cookery Sci, 26, 214-219

37. Jung J, Lee NK, Paik HD (2017) Bioconversion, health benefits, and application of ginseng and red ginseng in dairy products. Food Sci Biotechnol, 26, 1155-1168

38. Choi CY, Park EH, Ju YW, Kim MD (2016) Increase of epigallocatechin in green tea extract by lactic acid bacteria fermentation. Microbiol Biotechnol Lett, 44, 62-67

39. Yun YJ, Lee A, Nguyen TMT, Park JT, Yun SM, Kim J (2018) Bioconversion of onino extract to improve the bioavailablility of quercetin glycoconjugate. Korean $\mathbf{J}$ Food Sci Technol, 50, 391-399

40. Kim HG, Kim KY, Cha CJ (2007) Screening for ginseng-fermenting microorganisms capable of biotransforming ginsenosides. Korean J Microbiol, 43, 142-146 